\title{
Chapter 4: Russia's Food Security and Impact on Agri-Food Trade
}

\author{
Linde Götz, Maximilian Heigermoser, \\ and Tinoush Jamali Jaghdani
}

\section{INTRODUCTION}

The emergence of food security as a core component of Russia's food policy and as a political priority is important because it affects domestic food production and the way in which Russia interacts with the international agri-food market. Whereas the Soviet period witnessed Russia as a large grain importer, in the 1990s Russia changed to a meat importer. In both periods, Russia's role as an importer meant that Russia was a significant player in the international food market (see Chapter 1). Since 2000,

L. Götz (凶) · M. Heigermoser · T. J. Jaghdani

Leibniz-Institute of Agricultural Development in Transition Economies (IAMO), Halle, Germany

e-mail: Goetz@iamo.de

M. Heigermoser

e-mail: heigermoser@iamo.de

T. J. Jaghdani

e-mail: jaghdani@iamo.de

(C) The Author(s) 2022

S. K. Wegren and F. Nilssen (eds.), Russia's Role in the Contemporary

International Agri-Food Trade System, Palgrave Advances

in Bioeconomy: Economics and Policies,

https://doi.org/10.1007/978-3-030-77451-6_5 
Russia's food and agrarian policy has prioritised less dependence on food imports.

Essentially, Russia's contemporary food policy entails a trifecta of subpolicies, all of which are located at the protectionist end of the trade policy continuum: (1) food security policy, which has a variety of dimensions including reducing dependence on food imports; food security in the traditional sense, referring to consumption norms and nutrition; food safety; product tracing; and truth in labelling; (2) food self-sufficiency, which refers to the effort to increase agricultural production to meet domestic needs for certain basic commodities; and (3) import substitution policy, which refers to the attempt to substitute domestic production for imports where possible. As imports are substituted with domestically produced foods, consumers often face higher food prices. ${ }^{1}$

To achieve these goals of food policy and its subcomponents, Russian policymakers have different instruments to choose from: import taxes, non-tariff barriers, export quotas, and import bans against companies and countries. The subcomponents of food policy and the instruments used are united in trying to reduce the presence of agri-food imports in Russia's domestic food market. This protectionism provides incentives for domestic producers to increase their production. Protectionism has been combined with higher investments in the domestic agricultural sector through comprehensive financial subsidies. ${ }^{2}$

Russia's food policy frames the way in which Russia interacts with other states in agri-food trade with carry over effects to other dimensions as well. Through food security, self-sufficiency, and import substitution, the Russian government aims not only to decrease Russia's food import dependency and to increase its food self-sufficiency, but also to consolidate Russia as a large agri-food exporting country, a feature explicitly discussed in the Food Security Doctrine adopted in 2020. Previously, in May 2018, President Vladimir Putin signed a decree instructing that the dollar value of Russia's agricultural exports reach $\$ 45$ billion by $2024 .^{3}$ In late 2020, Russia's Ministry of Agriculture extended the date by which that target value of exports would be reached to 2030 .

The purpose of this chapter is to examine the impact of food policy on Russia's domestic production and its role in the international food trade system. The chapter will explore the domestic ramifications of food security as well as the international implications through imports and exports. Section 2 below presents a brief review of Russia's food 
security policy, noting that policy has evolved from an import substitution policy towards a policy that also generates agricultural and food exports. Section 3 presents an overview of the domestic ramifications of import substitution policy, focusing on pork, poultry, beef, raw milk, and fruit and vegetables. Section 4 looks at the international implications of Russia's protectionism, using pork and wheat as case studies. Section 5 provides an outlook to how Russia's food security policy, self-sufficiency, and import substitution will affect its role in the international agri-food system in the medium-term future.

\section{Food Security, Self-Sufficiency, AND IMPORT SUBSTITUTION}

This section provides an overview of Russia's food security policy, which has changed from import protectionism and food self-sufficiency exclusively to also generating agri-food exports for international markets. It is important to emphasise that Russia's food security policy does not signify a withdrawal from international food markets, and this theme will be further elaborated. Food security does signify a change in Russia's role in the international food trade system from mainly a food importer to an importer and exporter, and it does signify a change in trading partners in terms of countries and regions.

\subsection{Russia's Food Security Doctrines}

In reaction to the spike in world food prices in 2007-2008, food security emerged as a significant economic and political variable in Russia that affects food trade policy, international relations, and domestic agrarian policy. ${ }^{4}$ The emergence of food security as a core component of food policy and as a political priority is important because it affects the way in which Russia interacts with the international agri-food market. Whereas during the Soviet period Russia was a large grain importer, in the 1990s Russia changed to a meat importer. In both periods, Russia's role as an importer was significant. Since 2000, food and agrarian policy has prioritised less dependence on food imports.

In Russia, the concept of food security extends beyond the generally accepted definition of 'food access, availability, food use and stability' as stated by the 1996 World Food Summit. ${ }^{5}$ Specifically, food security does not refer to the origin of food as opposed to self-sufficiency 
which is sensitive to where food originates. ${ }^{6}$ Rather, Russian policymakers place particular emphasis on reducing food import dependency and therefore use the terms food security and food self-sufficiency synonymously. ${ }^{7}$ Whereas many countries are protectionist on agricultural imports, and several nations have explicit food security policies, Russia is unique in that food security and food self-sufficiency are conflated, whereas in the literature the two terms are distinct. ${ }^{8}$ Also unique is that since at least 2009 Russia's food security has explicit connections to national security, more so than in Western countries. ${ }^{9}$

An indicator of the seriousness with which Russian policymakers approach food security was evidenced by the signing of Russia's first Food Security Doctrine in January 2010. The doctrine established specific selfsufficiency targets for several basic agricultural and food products, defined as the percentage of domestic production in the total supply of commodities. The original Food Security Doctrine was more than mere rhetoric, as policymakers repeatedly referred to the doctrine and its standards for self-sufficiency to guide food and agrarian policy. That said, the Food Security Doctrine was not hard protectionism, as the dollar value of food imports into Russia continued to increase during 2010-2013. The original doctrine acquired extra importance when, on 7 August 2014, Russia implemented a food import ban on a wide range of agri-food products from the European Union (EU), the United States of America (USA), Norway, Canada, and Australia. The original ban was renewed several times and in late 2021 was extended through 2022. The food import 'countersanctions' were implemented by Russia in retaliation to Western sanctions over the Ukrainian crisis. It is important to note that countersanctions did not signal the end of Russia as a food importer. Instead, Russia changed food trade partners and began to trade more with China (see Chapter 7), within the Eurasian Economic Union (see Chapters 6 and 8), and the Middle East (see Chapter 9). Countersanctions did, however, bring decreased food trade between Russia and the European Union, and between Russia and the United States (see Chapter 10). Thus, neither the Food Security Doctrine nor the food embargo signalled Russia's withdrawal from the global food market, but rather a change with whom it traded.

The impact of the original Food Security Doctrine and countersanctions are beyond the scope of this chapter but have been discussed elsewhere. ${ }^{10}$ The success of the original doctrine, plus the impressive growth in domestic food production, led to the signing of a new Food 
Security Doctrine by President Putin in January 2020. ${ }^{11}$ The new 2020 Doctrine explicitly mentions the expansion of agri-food exports, which marks a significant change in Russia's role in the international food system compared to the period leading up to $2018 .^{12}$ In addition to agricultural products, Russia is also among the major global producers of fish from wild fisheries and aquaculture. The development of the fishery and aquaculture sectors is supported by the 'Strategy for Development of Agriculture and Fisheries Through 2030', which was approved by Prime Minister Mikhail Mishustin and published in April 2020. ${ }^{13}$

The Food Security Doctrine and various strategies for different commodities and products should be understood as having economic importance in that they impact domestic food production, and political importance in that they frame food trade interactions with other states. In terms of the theme of this book, these political acts define the nature of economic interactions and the underlying strategy of those interactions. Food security, self-sufficiency, and import substitution did not just occur accidentally or organically. They were deliberate policy choices by policymakers. Their decision reflected a calculation to enhance national security and as an appeal to rising nationalism in Russia. Those decisions impact Russia's international interactions and role in the global food system.

\section{Domestic Ramifications of Food Security Policy}

Food policy and its subcomponents have domestic and international dimensions. This section focuses on the domestic ramifications and provides an overview of the main agricultural import sectors which are targeted by Russia's food security policy. In particular, poultry, pork, beef, and raw milk are protected by Russia's food import ban against competition from producers in Western countries, while investments in those products are subsidised by the government. We also cover fruit and vegetables since they receive greater attention within the 2020 Food Security Doctrine. The basic takeaway is that for countersanctions and trade protectionism to work, domestic food production needs to increase, and the country needs to maintain or increase self-sufficiency for basic food groups. 


\subsection{Domestic Structure of Production}

We start with a brief discussion of the structure of food production. The change in the structure of production relates to food security because Russia has become increasingly dependent on output from agricultural organisations and agroholdings. This dependence in turn means that organisations and agroholdings receive most of the investment credit and subsidies from the state. Policymakers have an interest in a strong, vibrant large farm sector, both for domestic food production and export potential. The emergence of agroholdings has also led to a concentration of production in just a few companies for several commodities. In 2019, for example, the top 25 companies accounted for one-half of total meat production in the country, and 63 percent of meat production coming from agricultural organisations. ${ }^{14}$ The rate of growth in meat production among the top 25 companies is nearly four times as fast as the rate of growth in meat production in general.

While not a direct outcome of food security policy, one of the notable characteristics in Russia's agrarian system is a change in the structure of production during the 2000s compared to the 1990s. Russia has three categories of food producers: agricultural enterprises (also called organisations), which have subcategories; households, again with different subcategories; and private farms. Whereas agricultural organisations were in decline during the 1990s, since 2000 there has been a clear and unmistakable trend towards dominance by agricultural organisations. In particular, among agricultural organisations, a specific subset of farms organisations called agroholdings is the largest, representing mega-farms often with several hundred thousand hectares each. ${ }^{15}$ Agroholdings use industrial methods of production and are characterised by high vertical integration, reflecting that they own several stages of the supply chain. In some cases, agroholdings have full control over the whole food supply chain. During the 1990s, households accounted for more than 50 percent of the ruble value of agricultural production. Household production declined in volume and relative contribution after 2000, however, and by 2019 agricultural organisations accounted for 58 percent of Russia's agricultural production, while the contribution from household production decreased to 28 percent (based on ruble value). Overall, during the 2000-2019 period, the ruble value of agricultural production increased more than fivefold, with the value of production from agricultural organisations leading the way. Thus, a distinct positive is increased volume and 
value of production from agricultural organisations; on the other hand, food security and food self-sufficiency have increased vulnerability to the financial and production health of agricultural organisations.

Turning to specific commodities, poultry production has always been dominated by large agricultural organisations who have on average about 320,000 chickens per organisation. ${ }^{16}$ Organisations' share in production increased since 1996 from 60 percent up to 92 percent in 2019, thereby decreasing the importance of households, which have, on average, 33 chickens. Concurrently, national poultry production increased from about 1 million tonnes to 6.7 million tonnes. Of particular note is the extreme concentration of production by a handful of agroholding companies. In 2018 , for example, the top 20 poultry companies accounted for two-thirds of the production of Russia's broilers. ${ }^{17}$

Pork production is also dominated by agricultural organisations. By 2019,87 percent of organisations had more than 10,000 pigs, while households have an average of 4.5 pigs (and a significant number of households have no pigs at all). Similar to poultry, the increasing importance of agricultural organisations in the pork sector led to strong growth in production, rising from 2 million tonnes in 1999 to 5 million tonnes in 2019. Similar to poultry, there is significant concentration. In 2018, the top 20 pig raising companies accounted for 56 percent of the nation's pork production. ${ }^{18}$ There has also been a geographical structural shift. The expansion of domestic pork production was accompanied by a regional shift from the Southern Federal District to the Central Federal District. Since 2006, pork production has been increasingly concentrated in Belgorod, an oblast about $600 \mathrm{~km}$ south of Moscow that accounts for almost 20 percent of Russia's total pork production today. On the other hand, pork production in Krasnodar Krai and Rostov Oblast in the Southern Federal District has decreased significantly, two regions that previously were leading pork producers.

The production structure is different in the beef and milk sectors. Households average five cattle, of which three are typically milk cows; while medium-sized private farmers and individual entrepreneurs average 62 cattle, of which 32 are typically milk cows. Overall, households accounted for 54 percent of beef and 37 percent of raw milk production in 2019, although these percentages have been steadily decreasing in recent years. ${ }^{19}$ Agricultural organisations average 785 cattle per farm, of which 330 are milk cows, accounting for 54 percent of raw milk and 36 
percent of beef production in 2019. Total raw milk production has stagnated at around 30-31 million tonnes for many years, the share of raw milk produced by commercial farms has been increasing especially since 2014 , accounting for 63 percent of production in $2019 .^{20}$

Since the Russian government now includes vegetables and fruit in the 2020 Food Security Doctrine, we take a closer look at the structure of production for these two sectors. Unlike the meat sector, the production of fruit and vegetables did not experience a comparably strong decline during the early post-Soviet years. This occurrence might be explained by the high share of production from households, who did not experience the declines that large farms did, although more recently households' share is decreasing similar to meat production. Households accounted for about 60 percent of open ground/field vegetable production in 2019, while the share from agricultural organisations was 20 percent. Vegetable production from private farmers and individual entrepreneurs has also increased, reaching 20 percent of total production in 2019. The primary vegetable producing areas are located in the Southern Federal District and Central Federal District. These two districts account for about 50 percent of Russia's total area devoted to vegetable production. In contrast to open field vegetable production that is dominated by household production, large agricultural organisations dominate vegetable production in greenhouses. With the strong production growth observed since 2014, the share from agricultural organisations amounted to 70 percent of greenhouse vegetable production in 2019. Overall, greenhouse vegetable production has slightly increased in the recent years, accounting for about 14 percent of total vegetable production in 2019. The situation for fruit production is similar to open ground vegetable production. In 2019 households accounted for 65 percent of production, while agricultural organisations produced 28 percent.

\subsection{Food Self-Sufficiency}

The domestic dimension of Russia's food security includes a quest to improve food self-sufficiency. Figure l presents data on production, trade, and self-sufficiency for several commodities (see Fig. 1). First, for poultry and pork, self-sufficiency (calculated as the share of domestic production in consumption) has increased since 2010 due to higher production, while imports have decreased. According to Russian government data, the country attained self-sufficiency of 97 percent for poultry and 100 

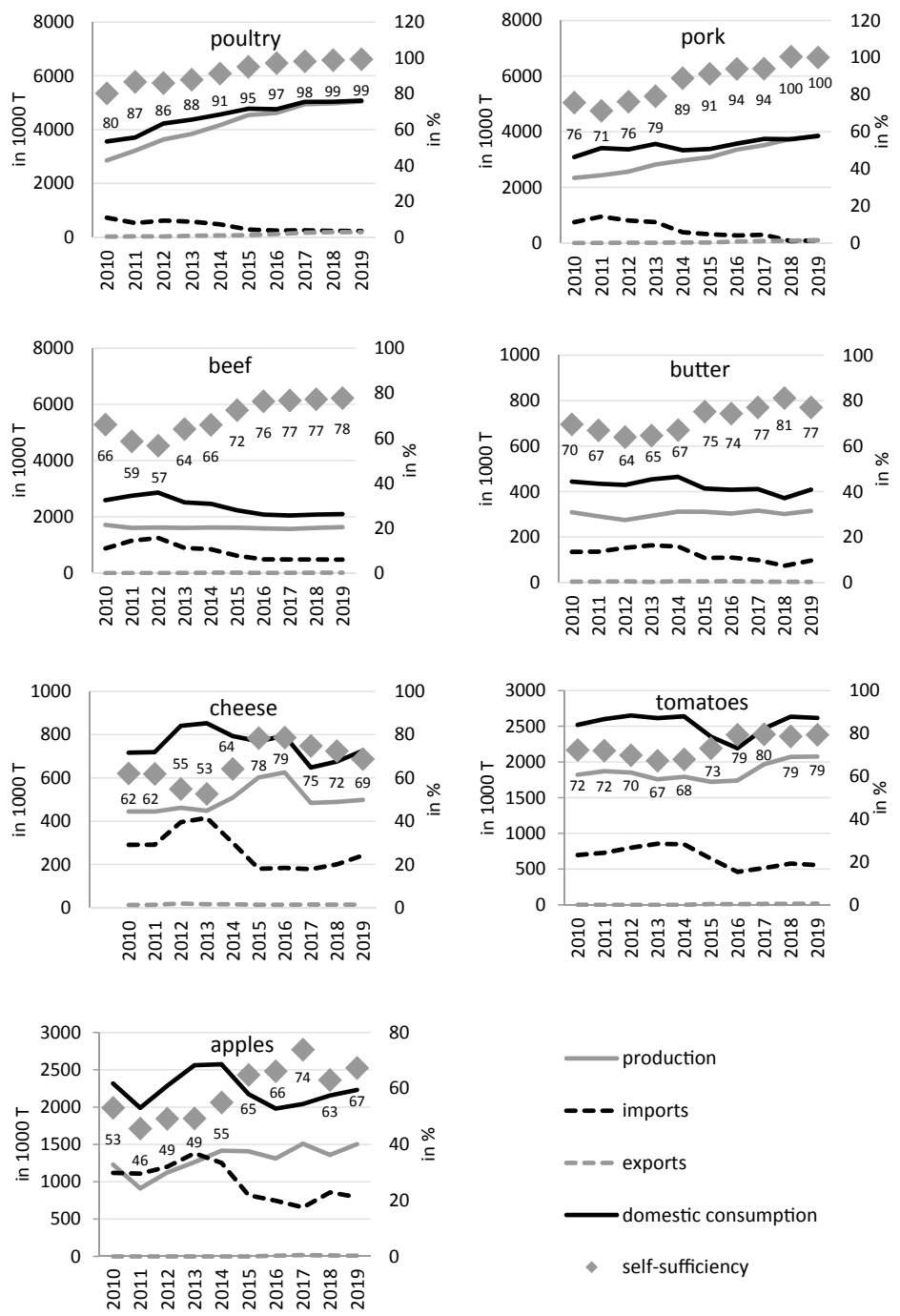

Fig. I Development of production, trade, and self-sufficiency for selected commodities (Note Production of poultry, pork, and beef refers to the production of slaughtered meat as only slaughtered meat is traded. Sources Authors' calculations from Rosstat data, various years; data from EMISS Gosudarstvennaia statistika, https://www.fedstat.ru/, accessed 20 August 2020; United States Department of Agriculture, Foreign Agricultural Service, 'PS\&D: Production, Supply, and Distribution', https://apps.fas.usda.gov/psdonline/app/index. html\#/app/advQuery, accessed 20 August 2020) 
percent for pork despite a simultaneous increase in domestic consumption. Russia is on the cusp of turning into a net exporter for poultry and pork. Even though beef production has been in long-term decline, selfsufficiency for beef increased to 78 percent in 2019, the result of lower consumption and substitution by consumers. There is some evidence that beef production has started to slightly increase recently. Russia remains a net importer of beef, although imports are declining thanks to higher yields from pedigree animals.

Similar to beef, self-sufficiency for butter increased to 77 percent in 2019. Production remained constant, but domestic consumption decreased. In addition, the Russian market for dairy products (except cheese) was increasingly supplied by Belarus, which, as a member of the Eurasian Economic Union, has tax-free access to the Russian market. Despite Russia's recurrent temporary bans on the import of milk and dairy products originating from Belarus, (e.g. on milk in bulk from April 2018 until May 2019), evidence points to a continuing lively black trade of dairy products between Belarus and Russia. ${ }^{21}$

Unlike the butter market, Russia's cheese market was heavily affected by the import ban implemented in 2014, which led to the strong decrease in cheese imports. In contrast, the Russian cheese market could not be supplied by Belarus, and consequently domestic consumption of cheese in Russia decreased. Although the domestic production of cheese strongly increased in the aftermath of the food ban against Western countries, it soon started to decrease again, which was accompanied by strong decreases in domestic cheese consumption as well. Thus, self-sufficiency of cheese varies substantially, amounting to between 70 and 80 percent. Those developments could be linked to the well-known problems with cheese quality, resulting specifically from the use of vegetable fats as a substitute for milk fat, which is not sufficiently available in Russia. This prompted the Russian government to take measures to reduce the mixing of vegetable oils with dairy products. In particular, the reduced tax for palm oil was abolished and the value-added tax was increased to 20 percent in July 2019. In addition, new labelling rules were implemented, requiring information on the use of vegetable fats, especially palm oil, to be provided on the packaging.

Self-sufficiency in fresh apples, the most popular fruit in Russia, rose to about 80 percent in 2019. Apple imports heavily declined following the 2014 Russian food import ban, as large amounts of apples originating from Poland could no longer be supplied to the Russian market. We 
also observe a strong increase in the self-sufficiency of tomatoes, rising to about 80 percent in 2019 . Tomatoes are among the most commonly consumed vegetables in Russia, boosted by output from greenhouses. As domestic tomato production has risen, tomato imports from Turkey have decreased, and since 2016 Russia has placed a quota on the volume of tomato imports from Turkey.

The point of this discussion is that for several basic commodities, domestic production increased and the level of self-sufficiency rose. In that respect, the food self-sufficiency policy has been successful, although we note that those basic commodities do not represent the full spectrum of consumer demand. It is, therefore, a rather narrow definition of success. Further, and more important as far as this book is concerned, an increase in self-sufficiency does not mean that Russia has withdrawn from the global food market. We turn next to the international dimension of food security in the section below.

\section{INTERNATIONAL RAMIFICATIONS of Food Security Policy}

The fact that food security (in the Russian variant), food self-sufficiency, and import substitution lie at the protectionist end of the trade spectrum does not mean that Russia has withdrawn from being a significant player in the global food trade system. Russia continues to play an important role as a food importer, and despite food security policy the dollar value of its agri-food imports exceeded the dollar value of its agri-food exports until 2020. Chapter 1 in this book explains how Russia remains active in the global food market, and Chapters 6, 7, 8, and 9 show that Russia's agri-food trade is increasing vis-à-vis several different regions of the world as well as individual (non-western) countries. Further, as noted above, Putin's May 2018 decree and the 2020 Food Security Doctrine aspire to increase Russia's role as an agri-food exporter. Russia already has led the world in wheat exports in six of the seven agricultural years since 2014 . That said, there is no doubt that food security policy has affected Russia's foreign food trade, indicated at the macro-level by a decrease in the dollar value of food imports since 2014 and the introduction of the food ban. Some of the reduction is due to the 2014-2015 recession, and since then lower import values are due to changes in consumers' buying habits and preferences, the importation of food from lower-cost nations, as well as import substitution. The purpose of this section is to explore in more 
detail the impact of food security policy on foreign food trade. We use pork as a case study for imports, and grain as a case study for exports.

\subsection{Imports: Pork Trade}

Russia's pork sector illustrates the way in which food security and its protectionism along with import substitution affect trade relations and more broadly Russia's role in the international food trade system. ${ }^{22}$ For pork, increased domestic production, concerns over sanitary and health conditions and additives, and political considerations have led to a significant decrease in pork imports. Not only has the volume of pork decreased, but the composition of the countries of Russian pork imports has changed significantly as the country's pork import policy was modified (see Fig. 2).

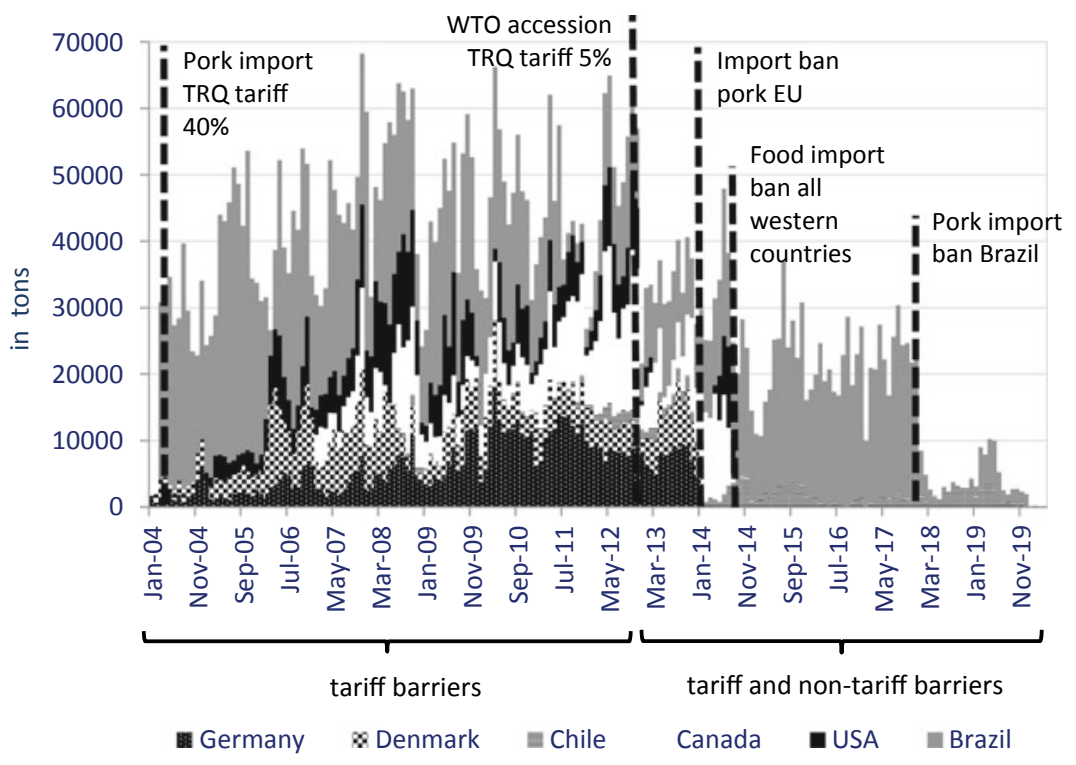

Fig. 2 Structure of Russia's pork imports and trade policies (Sources Linde Götz and Tinoush Jaghdani, 'Russia's agricultural import substitution policy: Price volatility effects on the pork supply chain', 57th Annual Conference of the German Association of Agricultural Economists, München, Germany, 13-15 September 2017; ITC, 'Trade Map', n.d. https://www.trademap.org/, accessed 20 August 2020) 
Protectionism for the pork sector began in 2003 with the introduction of a tariff-rate quota (TRQ), with an in-quota tariff of 40 percent and a prohibitive out-of-quota tariff of 68 percent. Poultry and beef were also subject to TRQs. For pork, the TRQ began at 500,000 tonnes although it was marginally reduced over time, falling to 472,000 tonnes in 2011 . This policy was in effect until August 2012, when the in-quota tariff was reduced to 0 percent and the out-of-quota tariff to 65 percent, while the quota was reduced to 400,000 tonnes (exclusive of trimmings, which add another 30,000 tonnes) as a condition of Russia's accession to the World Trade Organization (WTO). ${ }^{23}$ During this time, Russia's pork imports primarily originated from Germany, Denmark, Canada, the United States, and Brazil.

The reduction in Russia's in-tariff quota and the rise in domestic production led to a decrease in pork imports following entry into the WTO. In addition, non-tariff barriers, such as sanitary and phytosanitary measures and technical barriers to trade, were increasingly applied to reduce pork imports. As an example, since December 2012, selected pork exporting companies in Germany were banned by the Russian government and were no longer allowed to export pork to Russia. This ban was extended to all companies located in Bavaria, North Rhine-Westphalia, and Lower Saxony in February 2013. Rossel'khoznador, Russia's Federal Service for Veterinary and Phytosanitary Surveillance, justified these interventions by pointing to non-compliance with Russia's phytosanitary and hygiene standards.

In January 2014, pork exports from the European Union to Russia were completely banned due to the outbreak of the African swine fever in the Baltic countries. ${ }^{24}$ In addition, pork imports from Germany and Denmark completely stopped. Then, in August 2014, pork exports from all Western countries to Russia were banned as a result of the agricultural import ban imposed as countersanctions because of the Ukrainian crisis. Consequently, pork imports from Canada and the United States were blocked as well and Russia replaced those suppliers by importing almost exclusively from Brazil and small quantities from Chile. In December 2017, Russia imposed a ban on pork imports originating from Brazil. Rossel'khoznadzor justified those restrictions by citing food safety concerns resulting from the reported presence of the feed additive ractopamine. ${ }^{25}$ Although the import ban against Brazil was lifted in November 2018, selected pork production plants in Brazil remained banned. ${ }^{26}$ Subsequently, pork imports from Brazil did not recover to the pre-ban level. 
Since 2014, Russia's agricultural import ban against Western countries has been extended several times and is currently valid until the end of 2022. As a result, Russia's pork imports from Western nations decreased to zero.

In 2020, the tariff rate quota for pork was abandoned altogether and replaced by a flat 25 percent tariff on all pork imports. The combination of higher domestic production and the import tariff led to an overall decline in pork imports. During 2018-2019, Russia imported about 100,000 tonnes of pork annually, but during the first half of 2020 the volume of imported pork declined to just over 1,000 tonnes. ${ }^{27}$ Thus, Russia's global role as a pork importer has changed. A similar situation occurred with poultry, although we do not discuss that commodity here, but the same dynamics were at work: food security and protectionism, import substitution, and a healthy dose of politicised trade, all of which contributed to self-sufficiency and a significant decline in poultry imports.

\subsection{Exports: Grain Trade}

Perhaps the best example of Russia's new role in the international agrifood trade system is its emergence as a major grain exporter. Through the 2019/2020 agricultural year, Russia led the world in the volume of wheat exports in five of the past six years and was on track to lead again in the 2020/2021 agricultural year on the strength of the second largest harvest in post-Soviet history. An overview of grain production, imports and exports, and export share is shown in Fig. 3.

In contrast to pork and other meat products, Russia's grain sector is not protected by food security or trade policies. Grain imports have decreased to almost nothing (see Chapters 2 and 10 in this book). But concerns over food security continue to influence grain trade policy nonetheless through wheat export restrictions, which is to say that Russia is not a completely free trader. Its trade restrictions on grain trade at various times point to the fact that Russia's international role in global grain trade is subject to domestic food security concerns.

Russia has a history of restricting wheat exports as a crisis policy measure that aims to stabilise domestic prices, counteract food price inflation, and dampen feed prices. In response to the spike in global commodity prices in 2007-2008, the Russian government restricted grain exports through an export tax of up to 40 percent over concerns that exports would try to maximise their profits at the cost to domestic food 


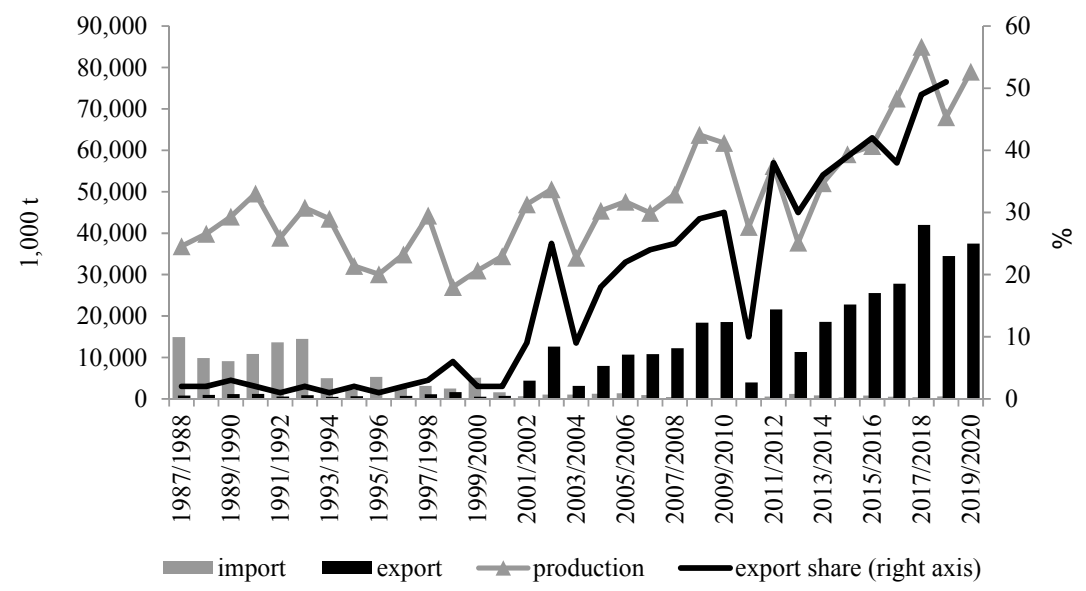

Fig. 3 Production, imports, exports, and export share for wheat in Russia (Note Until 1991 wheat production of the Russian Socialist Federative Soviet Republic. The values for 2019/2020 represent predictions (Source United States Department of Agriculture, Foreign Agricultural Service, 'PS\&D: Production, Supply, and Distribution', https://apps.fas.usda.gov/psdonline/app/index.html\#/app/ advQuery, accessed 20 August 2020)

security. When Russia's wheat production was hit by serious drought and heat in 2010 , leading to a loss of 30 percent of the harvest on average, a complete ban on grain exports was implemented from August 2010 to July 2011. In 2015, the devaluation of the ruble during 2014-2015 prompted the Russian government to establish a grain export tax of 15 percent with an additional payment of 7.5 Euro per tonne in order to prevent a surge in wheat exports. The intent was to prevent domestic shortages and high food inflation.

Finally, in January 2020 the government announced that going forward it may implement a grain export quota during the second half of an agricultural year (January-June), depending on conditions. Russia is not the only country to use export quotas, and ordinarily governments would not be concerned about food shortages in the midst of the second largest harvest in post-Soviet history. ${ }^{28}$ Therefore, the export quota suggests that concerns over food insecurity may be more political than physiological. ${ }^{29}$ For 2020, Russia's grain export quota was set at 
7 million tonnes starting in April, limiting the export of grain to nonmember states of the Eurasian Economic Union to June 2020. ${ }^{30}$ The export quota was not well received by grain exporters who complained about the loss of revenue. In addition, the Russian government placed export bans on sunflower seed, rice, barley, and corn starting in April 2020 to the end of June countries outside the EAEU, even though no domestic shortages were reported. In 2021, the export quota on wheat began in January and extended to the end of June.

\section{OUTLOOK}

Food security policy, self-sufficiency, and import substitution have guided domestic food policy for more than a decade. They are unlikely to go away anytime soon, as witnessed by the adoption of the 2020 Food Security Doctrine. Further, food security considerations affect agri-food imports and exports as the discussion in the previous section illuminated. Thus, food security frames international interactions, influences trade partners and relations with them, and defines the role that Russia plays in the international food system.

Going forward, we may expect continued emphasis on self-sufficiency. Russia is essentially self-sufficient in pork and poultry, while continuing as a net importer of beef and butter, as well as fruit and vegetables. The future development of those sectors strongly depends on whether their markets will continuously be shielded from international competition by Russia's food import ban. If the food import ban against Western countries would be removed, it can be expected that imports of beef and dairy products, as well as fruit and vegetables, would increase. If the food import ban remains and continues to protect domestic producers vis-àvis international competition, production growth in those sectors can be expected to be more dynamic. However, Russia's food security policy is an element of foreign policy, and geopolitics will decide whether the Russian food import ban is sustained or abolished. ${ }^{31}$

In terms of food exports, short of catastrophic events such as megadrought or years of anomalous heat, we expect Russia to remain a strong wheat exporter. ${ }^{32}$ That said, Russia's wheat market remains challenged by large distances between the grain-producing regions and access points to the world market at the Black Sea and also the Pacific Ocean. ${ }^{33}$ Although Russia has significant potential to increase grain production, the question is to what extent additional grain production can be mobilised 
and transformed into grain export supply on the world market. Since grains, and in particular wheat, is the primary agricultural export product, the political will to catalyse the mobilisation of grain exports by financing investments in transport and port infrastructure and subsidising the recultivation of land is high. However, growing livestock production will increase domestic demand for grains and thus reduce the grain export potential. Nonetheless, given the large additional grain production potential, a rather weak ruble, and strong political support for upscaling grain transport infrastructure for domestic and international trade, it can be expected that wheat exports will further increase, and Russia will continue to be among the dominant wheat exporters in the world. However, continuing restrictions of wheat exports by the Russian government, and increasing domestic livestock production may moderate wheat export growth.

The bottom line is that food security has not prevented Russia from playing a major role in the international food trade system, and that is likely to remain true. We expect Russia to continue its role as an importer of certain raw products for which it may not attain self-sufficiency (as well as the importation of packaged and processed foods ready for immediate consumption). And we expect Russia to maintain and expand its role as an agri-food exporter to more than 100 countries in the world. Russia as a player in the global food system is here to stay, even with protectionist food security policies.

\section{Notes}

1. Tleubayev Alisher, Tinoush Jaghdani, Linde Götz, and Miranda Svanidze, 'The effects of trade policy on domestic dairy market: the case of Russian food import ban on regional cheese market integration in Russia', International Conference of Agricultural Economists, 28 July-2 August 2018, Vancouver, Canada. Available at https://ageconsearch.umn.edu/record/ 277373 ? $\mathrm{ln}=\mathrm{en}$.

2. See Vasyl Kvartiuk and Thomas Herzfeld, 'Redistributive Politics in Russia: The Political Economy of Agricultural Subsidies', Comparative Economic Studies, https://doi.org/10.1057/s41294-020-00131-2, August 2020. Accessed at https://link.springer.com/content/pdf/10. 1057/s41294-020-00131-2.pdf. Accessed 2 November 2020.

3. See Stephen K. Wegren, 'Can Russia's Food Exports Reach $\$ 45$ Billion in 2024? Post-Communist Economies 32, no. 2 (2020): 147-75. 
4. See Stephen K. Wegren, Alexander Nikulin, and Irina Trotsuk, Food Policy and Food Security: Putting Food on the Russian Table (Lanham, MD and London, UK: Lexington Books, 2018).

5. Food and Agriculture Organisation, 'Rome Declaration on World Food Security and World Food Summit Plan of Action', World Food Summit, 13-17 November 1996. http://www.fao.org/3/w3613e/w36 13e00.htm. Accessed 2 November 2020.

6. Stephen K. Wegren and Christel Elvestad. 'Russia's Food Self-Sufficiency and Food Security', Post-Communist Economies 30, no. 5 (2018): 565-87.

7. Stephen K. Wegren, Alexander Nikulin, and Irina Trotsuk, 'The Russian Variant of Food Security', Problems of Post-Communism 64, no. 1 (2017): 47-62; and Stephen K. Wegren, Frode Nilssen, and Christel Elvestad, 'The Impact of Russian Food Security Policy on the Performance of the Food System', Eurasian Geography and Economics 57, no. 6 (2016): 67199.

8. Jennifer Clapp, 'Food Self-Sufficiency: Making Sense of It, and When It Makes Sense', Food Policy 66 (2017): 88-96.

9. Stephen K. Wegren, 'Russia’s Food Policies and Foreign Policy', Demokratizatsiya: The Journal of Post-Soviet Democratization 18, no. 3 (2010): 189-207.

10. Wegren and Elvestad, 'Russia's Food Self-Sufficiency and Food Security: An Assessment'; Wegren, Nilssen, and Elvestad, 'The Impact of Russian Food Security Policy on the Performance of the Food System'; and Stephen K. Wegren, 'Effects of Russia's Food Embargo After 5 Years', Russian Analytical Digest no. 241 (November 2019): 6-10.

11. United States Department of Agriculture, Foreign Agricultural Service, 'New Food Security Doctrine Adopted', GAIN Report RS2020-0003. 4 February 2020. www.fas.usda.gov/data. Accessed 18 August 2020. The food self-sufficiency targets in the 2020 Food Security Doctrine were slightly increased from 80 to 90 percent for sugar and vegetable oils, and from 80 to 85 percent for fish products compared to the 2010 Food Security Doctrine. In addition, food security targets were introduced for vegetables, melons, and gourds (90 percent), fruit and berries (60 percent), and seeds of key domestic agricultural crops (75 percent). The food security targets defined in the Food Security Doctrine 2020 had already been reached for the majority of products in 2019. Exceptions were milk and dairy products ( 82 percent achieved versus the 90 percent target), fruit and berries (34 percent versus the 60 percent target), and seeds of key agricultural crops ( 85 percent of the target fulfilled for grain seeds).

12. These objectives are in line with the presidential decree 'On the National Goals and Strategic Tasks of the Development of the Russian Federation for the Period up to 2024'. Announced by President Putin in May 
2018, the decree communicates the goal of increasing Russia's agricultural exports to $\$ 45$ billion USD in 2024. 'Presidential Decree on national objectives and strategic tasks of Russian Federation's development in the period up to 2024'. 7 May 2018. http://extwprlegsl.fao.org/docs/pdf/ rus182356E.pdf. Accessed 18 August 2020.

13. United States Department of Agriculture, Foreign Agricultural Service, 'Strategy for Development of Agriculture and Fisheries Through 2030', GAIN Report RS2020-0026, 14 May 2020. www.fas.usda.gov/data. Accessed 1 November 2020.

14. Tat'iana Kulistikova, 'Lidery rynka ukrepliaiut pozitsii', Agroinvestor, no. 6 (June 2020): 59.

15. For a discussion of the origins and operation of agroholdings, see Dmitri Rylko, Irina Khramova, Vasilii Uzun, and Robert Jolly, 'Agroholdings: Russia's New Agricultural Operators', in Russia's Agriculture in Transition: Factor Markets and Constraints on Growth, ed. Zvi Lerman (Lanham, MD: Lexington Books, 2008), 95-133; V. Ia. Uzun and N. I. Shagaida, Agrarnaia reforma v postsovetskoi Rossii: Mekhanizmy i resul'taty (Moscow: Delo, 2015), 174-82; Wegren, Nikulin, and Trotsuk, Food Policy and Food Security: Putting Food on the Russian Table, 16-20; and Stephen K. Wegren with Alexander Nikulin and Irina Trotsuk, Russia's Food Revolution: The Transformation of the Food System (London and New York: Routledge, 2021), 62-70.

16. Dmitry Prikhodko and Albert Davleyev, Russian Federation: Meat Sector Review (Rome, Italy: FAO, 2014). http://www.fao.org/3/a-i3533e.pdf. Accessed 18 August 2020.

17. Wegren, Nikulin, and Trotsuk, Russia's Food Revolution, 68.

18. Ibid.

19. See Stephen K. Wegren, 'Understanding the Decline of Smallholders in Contemporary Russia', Outlook on Agriculture, https://doi.org/10. $1177 / 0030727020969201$, October 2020.

20. Petrick and Götz identify access to value chains for milk marketing as a decisive factor for on-farm herd growth. Small household farms especially do not often have access to value chains that connect small producers with spatially dispersed consumers. Thus, household producers are restricted to milk marketing directly to end consumers, which is of rather limited size, and does not provide opportunities for herd growth. See Martin Petrick and Linde Götz, 'Herd Growth, Farm Organisation and Subsidies in the Dairy Sector of Russia and Kazakhstan', Journal of Agricultural Economics 70, no. 3 (2019): 789-811.

21. See Wegren, Nikulin, and Trotsuk, Food Policy and Food Security: Putting Food on the Russian Table, 160-62.

22. See Linde Götz and Tinoush Jaghdani, 'Russia's agricultural import substitution policy: Price volatility effects on the pork supply chain', 
57th Annual Conference of the German Association of Agricultural Economists, München, Germany, 13-15 September 2017. Available at https://econpapers.repec.org/paper/agsgewil7/262003.htm.

23. United States Department of Agriculture, Foreign Agricultural Service, 'Customs Union Announces 2012 Meat and Poultry TRQs', GAIN Report RS1159, 28 December 2011. www.fas.usda.gov/data. Accessed 1 November 2020; United States Department of Agriculture, Foreign Agricultural Service, 'Russia 2018 Livestock and Products Annual', GAIN Report RS1828, 29 October 2018. www.fas.usda.gov/data. Accessed 1 November 2020.

24. In August 2016 the WTO declared that the Russian import ban on pork from the EU was illegal since it violates the WTO Agreement on the Application of Sanitary and Phytosanitary Measures.

25. Jose Roberto Gomes, 'Russia ban on Brazil meat exports may soon be reversed: ABPA', 21 November 2017. https://www.reuters.com/article/ us-russia-brazil-livestock-idUSKBNIDL1B6. Accessed 2 November 2020.

26. Reuters, 'Russia removes restrictions on two Brazilian beef plants - regulator', 29 November 2019. https://cn.reuters.com/article/brazil-russiameat-idINL1N2890HL. Accessed 2 November 2020.

27. Kommersant, 'Import svininy upal do minimal'nykh znachenii', 29 July 2020. https://agrovesti.net/news/indst/import-svininy-upal-dominimal-nykh-znachenij.html. Accessed 1 November 2020.

28. See Linde Götz, Feng Qiu, Jean-Philippe Gervais, and Thomas Glauben, 'Export Restrictions and Smooth Transition Cointegration: Export Quotas for Wheat in Ukraine', Journal of Agricultural Economics 67, no. 2 (2016): 398-419.

29. The argument that concerns over food security may be manufactured for political purposes was first made in Wegren, Nikulin, and Trotsuk, 'The Russian Variant of Food Security'.

30. Ministry of Agriculture of the Russian Federation, 'The Russian Government approved the Ministry's of Agriculture initiative on the grain export quota', 3 April 2020. www.mcx.gov.ru/en/news/Russian-Governmentapproved-the-grain-export-quota/. Accessed 1 November 2020.

31. Stephen K. Wegren, Frode Nilssen, and Christel Elvestad, 'The Impact of Russian Food Security Policy on the Performance of the Food System', 671-99.

32. See Linde Götz, Ivan Duric, and Oleg Nivievskyi, 'Regional Price Effects of Extreme Weather Events and Wheat Export Controls in Russia and Ukraine', Journal of Agricultural Economics 67, no. 3 (2016): 741-63.

33. See Miranda Svanidze and Linde Götz, 'Determinants of spatial market efficiency of grain markets in Russia', Food Policy 89 (2019). https://doi. org/10.1016/j.foodpol.2019.101769; and Miranda Svanidze and Linde 
Götz, 'Spatial market efficiency of grain markets in Russia: Implications of high trade costs for export potential', Global Food Security 21 (2019): $60-68$.

\section{Selected Bibliography}

Clapp, Jennifer. 'Food Self-Sufficiency: Making Sense of It, and When It Makes Sense'. Food Policy 66 (2017): 88-96.

Götz Linde, Ivan Duric, and Oleg Nivievskyi. 'Regional Price Effects of Extreme Weather Events and Wheat Export Controls in Russia and Ukraine'. Journal of Agricultural Economics 67, no. 3 (2016): 741-63.

Götz, Linde, Feng Qiu, Jean-Philippe Gervais, and Thomas Glauben. 'Export Restrictions and Smooth Transition Cointegration: Export Quotas for Wheat in Ukraine'. Journal of Agricultural Economics 67 no. 2 (2016): 398-419.

Götz, Linde and Tinoush Jaghdani. 'Russia's Agricultural Import Substitution Policy: Price Volatility Effects on the Pork Supply Chain'. 57th Annual Conference of the German Association of Agricultural Economists, München, Germany, 13-15 September 2017. https://econpapers.repec.org/paper/ags gewil7/262003.htm.

Kvartiuk, Vasyl and Thomas Herzfeld. 'Redistributive Politics in Russia: The Political Economy of Agricultural Subsidies'. Comparative Economic Studies, https://doi.org/10.1057/s41294-020-00131-2, August 2020. https://link. springer.com/content/pdf/10.1057/s41294-020-00131-2.pdf.

Petrick, Martin and Linde Götz. 'Herd Growth, Farm Organisation and Subsidies in the Dairy Sector of Russia and Kazakhstan'. Journal of Agricultural Economics 70, no. 3 (2019): 789-811.

Prikhodko, Dmitry and Albert Davleyev. Russian Federation: Meat Sector Review. Rome, Italy: FAO, 2014.

Rylko, Dmitri, Irina Khramova, Vasilii Uzun, and Robert Jolly. 'Agroholdings: Russia's New Agricultural Operators'. In Russia's Agriculture in Transition: Factor Markets and Constraints on Growth, ed. Zvi Lerman. Lanham, MD: Lexington Books, 2008, 95-133

Svanidze, Miranda and Linde Götz. 'Determinants of Spatial Market Efficiency of Grain Markets in Russia'. Food Policy 89 (2019). https://doi.org/10.1016/ j.foodpol.2019.101769.

Svanidze, Miranda and Linde Götz. 'Spatial Market Efficiency of Grain Markets in Russia: Implications of High Trade Costs for Export Potential'. Global Food Security 21 (2019): 60-8.

Tleubayev, Alisher, Tinoush Jaghdani, Linde Götz, and Miranda Svanidze. 'The Effects of Trade Policy on Domestic Dairy Market: The Case of Russian Food Import Ban on Regional Cheese Market Integration in Russia'. International 
Conference of Agricultural Economists, 28 July-2 August 2018, Vancouver, Canada. https://ageconsearch.umn.edu/record/277373?!n=en.

United States Department of Agriculture, Foreign Agricultural Service, 'Strategy for Development of Agriculture and Fisheries Through 2030'. GAIN Report RS2020-0026, 14 May 2020.

United States Department of Agriculture, Foreign Agricultural Service, 'New Food Security Doctrine Adopted'. GAIN Report RS2020-0003, 4 February 2020.

United States Department of Agriculture, Foreign Agricultural Service, 'Russia 2018 Livestock and Products Annual'. GAIN Report RS1828, 29 October 2018.

United States Department of Agriculture, Foreign Agricultural Service, 'Customs Union Announces 2012 Meat and Poultry TRQs'. GAIN Report RS1 159, 28 December 2011.

United States Department of Agriculture, Foreign Agricultural Service, 'Food Security Doctrine Adopted'. GAIN Report RS1008, 11 February 2010.

Wegren, Stephen K. 'Understanding the Decline of Smallholders in Contemporary Russia', Outlook on Agriculture, https://doi.org/10.1177/003072702 0969201 , October 2020.

Wegren, Stephen K. 'Can Russia's Food Exports Reach \$45 Billion in 2024?'. Post-Communist Economies 32, no. 2 (2020): 147-75.

Wegren, Stephen K. 'Russia's Food Policies and Foreign Policy'. Demokratizatsiya: The Journal of Post-Soviet Democratization 18, no. 3 (2010): 189-207.

Wegren, Stephen K., Alexander Nikulin and Irina Trotsuk. Russia's Food Revolution: The Transformation of the Food System. London and New York: Routledge, 2021.

Wegren, Stephen K., Alexander Nikulin, and Irina Trotsuk. Food Policy and Food Security: Putting Food on the Russian Table. Lanham, MD and London, UK: Lexington Books, 2018.

Wegren, Stephen K., Alexander Nikulin, and Irina Trotsuk. 'The Russian Variant of Food Security', Problems of Post-Communism 64, no. 1 (2017): 47-62.

Wegren, Stephen K. and Christel Elvestad. 'Russia's food self-sufficiency and food security: an assessment'. Post-Communist Economies 30, no. 5 (2018): 565-87.

Wegren, Stephen K., Frode Nilssen and Christel Elvestad. 'The Impact of Russian Food Security Policy on the Performance of the Food System'. Eurasian Geography and Economics 57, no. 6 (2016): 671-99. 
Open Access This chapter is licensed under the terms of the Creative Commons Attribution 4.0 International License (http://creativecommons.org/licenses/ by $/ 4.0 /$ ), which permits use, sharing, adaptation, distribution and reproduction in any medium or format, as long as you give appropriate credit to the original author(s) and the source, provide a link to the Creative Commons license and indicate if changes were made.

The images or other third party material in this chapter are included in the chapter's Creative Commons license, unless indicated otherwise in a credit line to the material. If material is not included in the chapter's Creative Commons license and your intended use is not permitted by statutory regulation or exceeds the permitted use, you will need to obtain permission directly from the copyright holder.

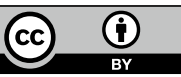

